\title{
Characterization and fluorescence of yellow biofilms in karst caves, southwest Slovenia
}

\author{
Janez Mulec ${ }^{1 *}$, Andreea Oarga-Mulec ${ }^{2}$, Rok Tomazin ${ }^{3}$, and Tadeja Matos ${ }^{3}$ \\ ${ }^{1}$ Karst Research Institute, Research Centre of the Slovenian Academy of Sciences and Arts, Titov trg 2, 6230 Postojna, Slovenia \\ ${ }^{2}$ Independent Researcher, Kolodvorska 1A, 6230 Postojna, Slovenia \\ ${ }^{3}$ Institute of Microbiology and Immunology, Faculty of Medicine, University of Ljubljana, Zaloška 4, 1000 Ljubljana, Slovenia
}

\begin{abstract}
Biofilms of different colours that colonize surfaces within karst caves represent a source of nutrients. They occur commonly and abundantly at sites with sediments, and close to seepages or underground rivers. Golden-yellow subaerial biofilms are particularly well observed because of their contrast with their surroundings, the characteristics of the pigment and recently, even more, due to the characteristics of light-emitting diode (LED) illumination. Yellow microbial biofilms were sampled from three caves in southwestern Slovenia, Dimnice, Križna jama and Sveta jama. The highest concentration of cultivable microbes $\left(2.33 \times 10^{8} \mathrm{CFU} / \mathrm{g}\right)$ and the biggest number of identified bacteria (66.0\%) were retrieved from a sample from Sveta jama. Using MALDI-TOF (Matrix-Assisted Laser Desorption/lonization Time-Of-Flight) for bacterial identification showed that different species of Pseudomonas prevailed in all samples. Yellow biofilms showed an absorption peak around $400 \mathrm{~nm}$, and two emission peaks, a major in the blue $(\sim 460 \mathrm{~nm})$ and a minor in the orange $(\sim 600 \mathrm{~nm})$ parts of the spectrum when excited at $405 \mathrm{~nm}$. Microbial mats that colonize surfaces are probably frequently overlooked in caves because they are difficult to observe when they have no pigmentation and the contrast with their surroundings is low. Additional studies are needed to aid the understanding of the role of pigmented biofilms and their interactions with underlying substrata in respect of the evolution of substrate micromorphology.
\end{abstract}

Keywords: $\quad$ underground; pigment; fluorescence; biomass; microbes; MALDI-TOF

Received 11 September 2014; Revised 4 March 2015; Accepted 9 April 2015

Citation: $\quad$ Mulec J., Oarga-Mulec A., Tomazin R. \& Matos T., 2015 - Characterization and fluorescence of yellow biofilms in karst caves, southwest Slovenia. International Journal of Speleology, 44 (2), 107-114. Tampa, FL(USA) ISSN 0392-6672. http://dx.doi.org/10.5038/1827-806X.44.2.1

\section{INTRODUCTION}

Speleothems of different shapes and colours, varying from black to orange to white are typical of many caves. The fluorescence of calcite speleothems is associated with humic and fulvic acids that are incorporated within the calcite crystal structure (Brennan \& White, 2013). These acids originate from overlying soils and are carried into caves by percolation water (McGarry $\&$ Baker, 2000) on a seasonal cycle (Ban et al., 2008). Spectroscopic analysis of speleothems of known age appears to provide a suitable tool to facilitate future study of changes in soil and vegetation over time (Brennan \& White, 2013).

Various biological mats occur alongside speleothems as a part of the subsurface habitat and decoration. They colonize rock, speleothems and sediment surfaces as yellow, white, pink, tan and gold-coloured spots, known among cave explorers as "sparkles" or "cave gold" for yellow-gold spots and as "cave silver" for those seen through condensed water droplets (Mulec, 2008). These subaerial biofilms, developed on solid mineral surfaces, are widespread under various climate and radiation conditions (Gorbushina, 2007). Especially in karst caves, the biofilms are observed in locations related to intense water condensation or seepages, and in the vicinity of underground rivers and cave entrances. Microbes colonizing surfaces in caves are responsible for changing the integrity of substrata, for example the deterioration of Palaeolithic paintings in Altamira Cave, Spain (Saiz-Jimenez et al., 2011). In these microbial mats Proteobacteria and Actinobacteria commonly dominate, followed by Bacteroidetes, Gemmatimonadetes, Firmicutes, Planctomycetes, Nitrospirae, Verrucomicrobia and Chloroflexi (Portillo et al., 2008; Portillo et al., 2009; Pašić et al., 2010). Similar dominant groups have been identified in lava tubes, and similarities were established among the extensive bacterial diversity of Terceira island in the Azores and the Big Island 
of Hawaii, two locations that are widely separated geographically (Dattagupta, 2014). In lava caves (Northup et al., 2011), but also in karst caves (Cuezva et al., 2012; Keiner et al., 2013), some microbial mats are associated with mineral formations.

Circular golden-yellowish colonies, which are also found as confluent growth, are the microbial mats most easily observed during cave exploration, other than those that are linked to lampenflora. Lampenflora is the term most commonly used to describe a community of organisms, mainly phototrophic, that develops near artificial light sources in show caves (Mulec, 2012). Such yellow mats in karst caves are periodically or constantly covered with a water film and some of them display strong adhesion to the substrata. A different fauna, especially troglophilic animals such as moths, flies and harvestmen, is observed at places with yellow mats close to cave entrances. The objective of the study was to undertake spectroscopic evaluation of yellow-pigmented subaerial biofilms and the applicability of MALDI-TOF (Matrix-Assisted Laser Desorption/Ionization Time-Of-Flight) technique for identification of cave bacteria on these samples, using the commercially available mass spectra database. Human colour perception of yellow subaerial biofilm in caves was considered further in relation to the spectroscopic characteristics of the pigment and lamps that are used to illuminate the caves.

\section{MATERIAL AND METHODS}

\section{Caves}

Yellow subaerial biofilm was sampled in three caves in Classical Karst area of southwestern Slovenia, where it was well developed and accessible to sample: Dimnice (No. 737 in the Cave Register of the Karst Research Institute ZRC SAZU and Speleological Association of Slovenia), Križna jama (Cave Register No. 66), and Sveta jama (Cave Register No. 1,158). All three caves have developed passages at different levels, with notable air flows in some galleries, and they are open to the public. Vegetation above these caves comprises shrub and forest. Temperature at the sampling sites was measured using a portable Kestrel 4,500 PocketWeather Tracker (USA).

Dimnice (453 3 '48.63"N 14²'25.65”E) has its main entrance at $567 \mathrm{~m}$ a.s.1., with $6,020 \mathrm{~m}$ of cave passages, and is formed in Upper Cretaceous limestone at the contact with overlying Palaeocene limestone and Eocene flysch rocks (Šikić et al., 1972). Two collapse dolines give access from the surface to the cave's dry upper passages, and a river that sinks into ponors at Velike Loče and flows through the lower passages (Malečkar \& Gospodarič, 1982). The two upper entrances and the flowing water influence the air circulation and temperature, and also the humidity of the linked passages. During the colder part of the year air from outside descends through the main shaft and mixes with the warmer cave air; this triggers powerful air circulation and the formation of mist. In the entrance section of the cave condensation is present on the walls at the junction between warm and cold air (Slabe, 1988), where microbial mats of different colours are developed. Yellow biofilms are sometimes covered with water droplets, which intensify their "golden" reflection. Yellow subaerial biofilms are also observed near the underground river, where there are alluvial sediment deposits (Fig. 1A). Biofilm was sampled on 18 March 2014; air temperature at the site was $5.5^{\circ} \mathrm{C}$. On the day of sampling air temperatures in the region were: mean air temperature $9.6^{\circ} \mathrm{C}$; maximum daily temperature $18.4^{\circ} \mathrm{C}$; and minimum $-2.5^{\circ} \mathrm{C}$. These data were from the Postojna Meteorological Station $\left(45^{\circ} 45^{\prime} 56.78\right.$ "N 14¹1'28.85”E; Slovenian Environment Agency: http://www.meteo.si). The cave attracts approximately 3,000 visitors per year.

The explored cave passages of Križna jama (454'42.25”N $14^{\circ} 27^{\prime} 51.04$ "E), which total 8,273 m in length (entrance at $629 \mathrm{~m}$ a.s.1.), are developed in Jurassic limestone with lenses of dolomite (Buser et al., 1967). The cave is connected directly to the surface via a natural entrance and also indirectly by a stream that sinks in Bloško polje and flows through the cave, where it influences air temperature and humidity (Gospodarič, 1974; Slabe, 1995; Bosak et al., 2010; Prelovšek, 2012). Križna jama is an active river cave with notable air-streaming due to a chimney effect. During the winter incoming air at the main entrance lowers the cave temperature, primarily in the lower part of the entrance passage (Slabe, 1989; Prelovšek, 2012). Because of the lower temperature of the cave walls, condensation generally occurs close to the main entrance and is not related to percolation water. Microbial biofilms of different colours, e.g. white, yellow, purple or brown, are commonly observed at locations with traces of sediments and percolation seepages, and they are often covered with water droplets (Fig. 1B, 1D). Yellow biofilm was sampled on 8 April 2014; air temperature at the site was $6.0^{\circ} \mathrm{C}$. On the day of sampling, surface air temperatures in the region were: mean air temperature $12.9^{\circ} \mathrm{C}$; maximum daily temperature $19.9^{\circ} \mathrm{C}$; and minimum $3.5^{\circ} \mathrm{C}$. Data were collected at the Postojna Meteorological Station (Slovenian Environment Agency: http://www.meteo. si). Around 5,000 tourists visit the entrance part of the cave each year.

Sveta jama $\left(45^{\circ} 35^{\prime 2} 23.66^{\prime \prime N} 13^{\circ} 51\right.$ '54.14”E), with its entrance at $420 \mathrm{~m}$ a.s.1., has $231 \mathrm{~m}$ of surveyed cave passages, all formed in Palaeocene/Eocene foraminiferal limestone (Pleničar et al., 1969). This cave has no active streamways to influence the cave climate conditions. Sveta jama is the only cave in Slovenia that serves as a church, and it attracts 2,000 tourists annually. In Sveta jama, microbial biofilms of different colours are scattered throughout the cave; confluent growth (continuous bacterial growth without discrete colonies) is rarely observed. Yellow biofilms are covered with water droplets (Fig. 1C). Subaerial yellow biofilm was sampled on 18 March 2014; cave-air temperature was $9.4^{\circ} \mathrm{C}$.

\section{Sampling and cultivation}

In all three caves yellow subaerial biofilms were sampled at sites where organic matter enters the underground system, at seeps that indicate good connectivity with the epikarst and in the vicinity of 


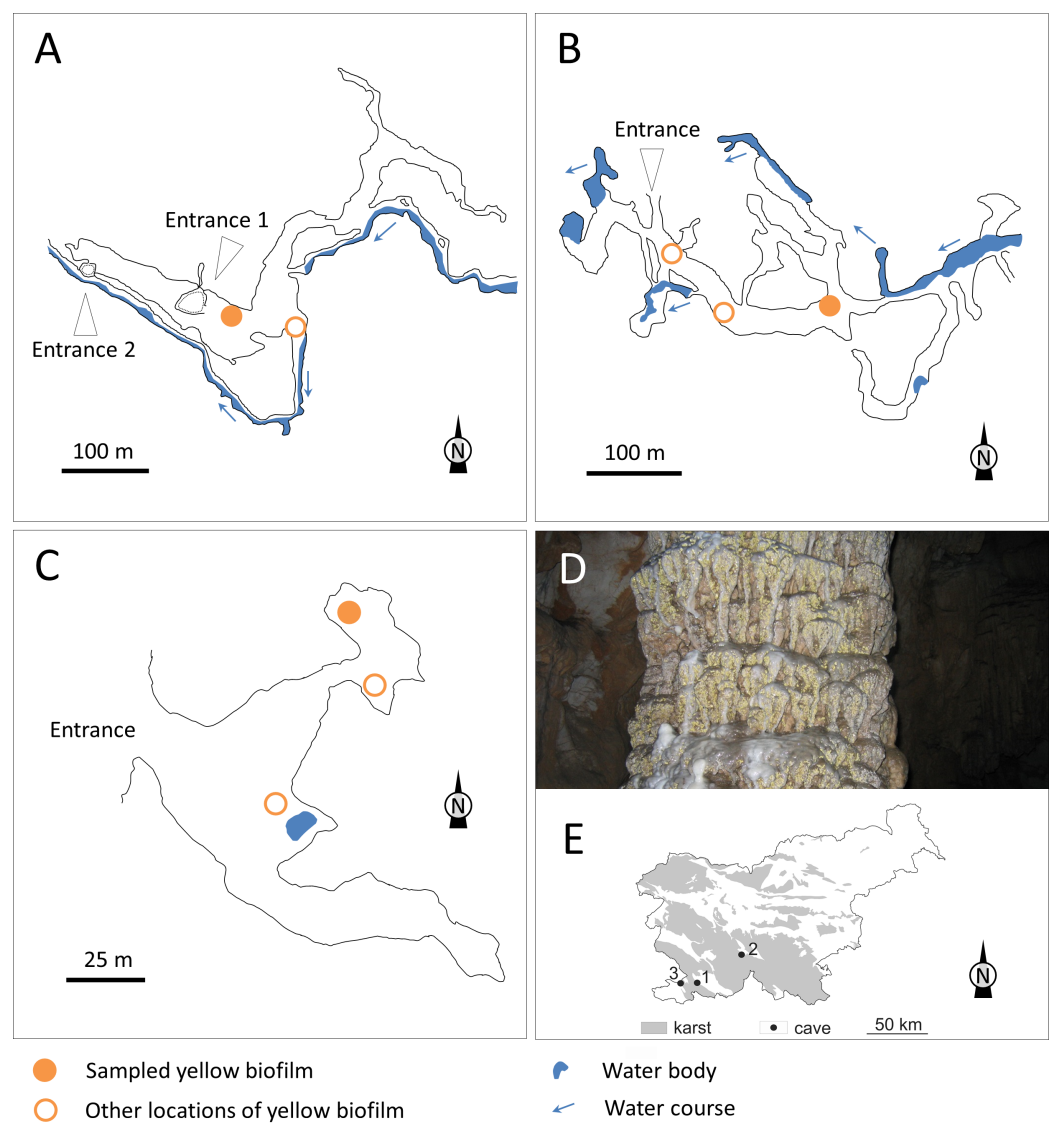

Fig. 1. Sampling locations of yellow subaerial biofilms and sampling sites. Ground plan of caves (adapted from Cave Register of the Karst Research Institute ZRC

SAZU and Speleological Association of Slovenia): A) Dimnice; B) Križna jama (after Prelovšek, 2012); C) Sveta jama. D) Sampling site of yellow biofilm in Križna jama, photograph by Janez Mulec; E) Map of karst in Slovenia with locations of caves (1 - Dimnice, 2 - Sveta jama, 3 - Križna jama).

underground rivers or natural entrances. Using sterile equipment, biofilm was scraped from rocky surfaces, transferred in a cool box to a laboratory, weighed, serially diluted in $0.9 \%$ physiological saline and plated on culture media. To mimic the natural environment, with evidently higher organic input compared to other parts of the caves, the selected cultivation media were not primarily supportive for oligotrophic microbes. Seven different media were used to propagate microbial colonies and to estimate the cultivable part of the community: (1) Nutrient agar (NA, Fluka); (2) Malt extract agar (MEA, Fluka); (3) Sediment Agar (SA), which contained $1.0 \%$ of old cave alluvial sediment and $1.5 \%$ agar; (4) RIDA ${ }^{\circledR}$ COUNT Total Aerobic Count (R-biopharm) for heterotrophic aerobic bacteria; (5) RIDA ${ }^{\circledR}$ COUNT E. coli/Coliform (R-biopharm) for Escherichia coli and coliforms; (6) RIDA ${ }^{\circledR}$ COUNT Salmonella/Enterobacteriaceae (R-biopharm) for enterobacteria and Salmonella; and (7) RIDA ${ }^{\circledR}$ COUNT Yeast\&Mold Rapid (R-biopharm) for yeasts and moulds. RIDA ${ }^{\circledR}$ COUNT plates provide a relative good proxy to monitor human impact underground (Mulec et al., 2012a; Mulec et al., 2012b).

Petri plates with NA, MEA, SA and RIDA ${ }^{\circledR} \mathrm{COUNT}$ for fungi were incubated aerobically at room temperature $\left(\sim 22^{\circ} \mathrm{C}\right)$, and $\mathrm{RIDA}^{\circledR} \mathrm{COUNT}$ selective media for Escherichia coli /coliforms and enterobacteria/ Salmonella were incubated at $37^{\circ} \mathrm{C}$. The inoculated plates were incubated at higher temperatures than those measured in the source caves. A previous study demonstrated that bacteria isolated from caves in Spain grew comparatively well at temperatures ranging from 13 to $45^{\circ} \mathrm{C}$; however, the metabolic profile of isolates differed, which indicated an adaptive response to temperature (Laiz et al., 2003). Cultivation lasted up to 96 hours. Visible colonies were quantified in terms of Colony-Forming-Units (CFU) per g. Incubation for 4 days retrieved mostly r-strategists (fast growers) and partly $\mathrm{K}$-strategists (slow growers) as the general conditions to study $\mathrm{r}$ - and K-strategists require 3 days to determine $r$-strategists and an additional 4-7 days for K-strategists at $20^{\circ} \mathrm{C}$ (Krišůfek et al., 2005).

\section{Characterisation of isolates}

195 bacterial isolates retrieved on NA, MEA, SA, RIDA ${ }^{\circledR}$ COUNT Total Aerobic Count and RIDA ${ }^{\circledR}$ COUNT Yeast\&Mold Rapid were inoculated on Blood Agar, incubated at room temperature for 24 to 48 hours and subjected to identification with MALDITOF using direct smear technique (Bruker Daltonik, Germany). Briefly, a smeared bacterial colony on the MALDI Steel plate was overlain with a photo-absorptive matrix - a-cyano-4-hydroxycynamic acid (CHCA) and left to dry before analysis with Bruker MALDI Biotyper RTC software version 3.1 (Seng et al., 2009). Quality of identification was assessed according to the manufacturer (Bruker Daltonik, Germany) using the LogScore value. If the obtained LogScore value for a given isolate was below 1.700, the identification was considered unreliable, and if the value was 1.700 or higher the identification was considered reliable.

\section{Spectroscopic analyses}

Pigments from the biofilms were extracted using three different solvents, deionized water, 90\% acetone and $96 \%$ ethanol. The biofilm from Sveta jama was extracted only in deionized water due to the small quantity of sampled material available. The suspension was incubated overnight in the dark (stability of pigment when exposed to light is not yet determined) and occasionally mixed vigorously. After centrifuging at 4,000 RPM for $10 \mathrm{~min}$, spectroscopic analysis was performed using a Lambda $25 \mathrm{UV}-\mathrm{Vis}$ Spectrometer (Perkin-Elmer, USA).

Before fluorescence analysis was carried out using a Luminiscence Spectrometer LS 30 (PerkinElmer, USA), the supernatant liquid was additionally centrifuged at $14,000 \mathrm{RPM}$ for 10 minutes. The excitation monochromator was set at $405 \mathrm{~nm}$ and the fluorescence monochromator was set to record emissions between 435 and $750 \mathrm{~nm}$.

The emission spectra of lamps used to light caves during explorations were measured in the laboratory, using a Jaz spectrometer (Ocean Optics, USA; detector 200-1,000 nm). These light sources included: a wax candle; a carbide lamp; a LED (Light Emitting Diode) lamp composed of 14 individual LEDs and a 
halogen bulb from a Petzl Duo headlamp (France); and a high performance LED from a Scurion 1300 headlamp (Switzerland).

\section{RESULTS AND DISCUSSION}

\section{Biofilm and microbial identification}

Differentconcentrations of cultivablemicroorganisms in terms of $\mathrm{CFU} / \mathrm{g}$ were retrieved on selected media. The highest number of isolates was retrieved in a sample from Sveta jama. In this sample 6.5-times more colonies were retrieved on SA than on NA. The concentrations of cultivable microbes on SA and NA for the other two caves were similar. In contrast, the Sveta jama sample on RIDA ${ }^{\circledR}$ COUNT plates for total heterotrophic bacteria showed the lowest concentration of cultivable microbes, $17 \times 10^{3} \mathrm{CFU} / \mathrm{g}$ (Table 1). Only a few coliform bacteria expressing $\beta$-galactosidase activity were retrieved, and there were no bacteria associated with faecal pollution, i.e., $E$. coli, enterobacteria. Except in one sample from Križna jama, the RIDA ${ }^{\circledR}$ COUNT Yeast\&Mold Rapid plates from the other two caves showed that fungi were present (Table 1). The low concentration of cultivable fungi, which are generally abundant in different cave microhabitats (Mulec et al., 2002), can be attributed to non-optimum selection of media. Yellow subaerial biofilms on solid surfaces represent live microbial biomass that serves as a nutrient source for other cave dwelling organisms. Fauna not only graze on biofilm, but also can help in microbial transmission in other parts of caves.

Table 1. Estimations of cultivable microorganisms using different cultivation conditions and media.

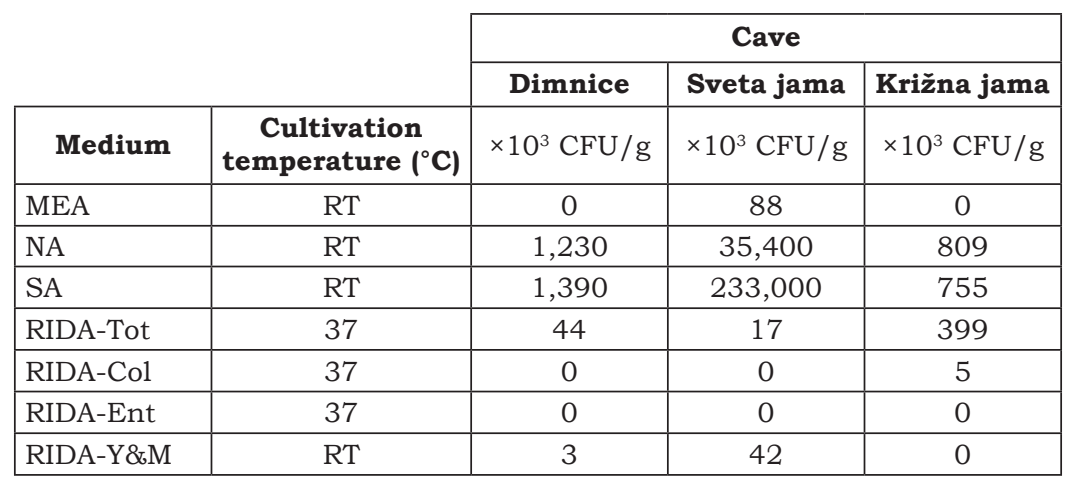

RT: room temperature, MEA: malt extract agar, NA: nutrient agar, SA: sediment agar, RIDA-Tot: IDA $^{\circledR}$ COUNT Total Aerobic Count, Rida-Col: RIDA ${ }^{\circledR}$ COUNT E. coli/Coliform, RIDA-Ent: RIDA ${ }^{\circledR}$ COUNT Salmonella/ Enterobacteriaceae, RIDA-Y\&M: RIDA ${ }^{\circledR}$ COUNT Yeast\&Mold Rapid.

Altogether 195 bacterial isolates from the three caves were subjected to identification by MALDI-TOF and 149 were identified according to the commercially available mass spectra library at species and genus level. The highest number of bacteria identified at species level was in a sample from Sveta jama (66.0\%), followed by Dimnice (43.5\%) and Križna jama (19.9\%). Different species of Pseudomonas prevailed, with the highest MALDI score value at 2.275 for Pseudomonas jessenii from Križna jama. The highest diversity at genus level was in a sample from Križna jama (Bacillus, Paenibacillus, Pseudomonas, Streptomyces and Variovorax), followed by Dimnice (Bacillus,
Flavobacterium, Pseudomonas and Streptomyces) and Sveta jama where only different representatives of Pseudomonas were identified (Fig. 2). The cultivable diversity of cave subaerial biofilm from another Slovenian cave (Pajsarjeva jama) revealed that the majority belonged to Streptomyces (25\%), Micrococcus (16\%), Rhodococcus (10\%) and Pseudomonas (9\%) (Velikonja et al., 2014). Not only Streptomyces (e.g. Shirling \& Gottlieb, 1966), but also Micrococcus (e.g. Brooks et al., 1980), Rhodococcus (e.g. Ichiyama et al., 1989) and Pseudomonas (e.g. Meyer, 2000) are well known pigment-producing bacterial genera. As in the current study, representatives of Bacillus and Paenibacillus were also commonly identified in Pajsarjeva jama, as well as Pseudomonas and Streptomyces. During the Pajsarjeva jama study (Velikonja et al., 2014) microbes were cultivated at $30^{\circ} \mathrm{C}$ for 5 weeks on nutrient-rich (glycerol-asparagine agar, peptone-yeast extract-brain heart infusion agar, 1,000-fold-diluted tryptic soy agar, starchcasein agar, malt-yeast extract agar, soil extract agar) and oligotrophic media (tap water agar). Results of culture independent studies and comparisons of environmental 16S rRNA on microbial mats from Spain, Slovenia, the Czech Republic, Portugal and Hawaii indicated that actinobacterial Pseudonocardinae and Gammaproteobacteria are the common dominant bacterial groups (Porca et al., 2012). Isolated fungi were not subjected to identification by MALDI.

Successful identification of microbes by means of the MALDI-TOF technique depends upon the limited availability of mass spectra in the database. Combination of MALDI-TOF with proper identification of environmental isolates, including cave isolates based on 16S rRNA and ITS sequences, will provide a tool for rapid, simple and cost-effective identification. In addition to species identification, the questions related to pigment characteristics can be studied simultaneously.

\section{Fluorescence of microbial biofilm and spectroscopy of yellow pigment}

Synthesis of pigments among bacteria is a common phenomenon; the majority of bacteria identified by MALDI-TOF from yellow mats can produce pigments and contribute to the colouring of caves. For example, Flavobacterium can produce the yellow carotenoid pigment, zeaxanthin (Dufosse, 2006). Some Bacillus also produce pigments (Tobie, 1945) and Variovorax has a xanthomonadin biosynthetic gene cluster (Zhou et al., 2013). The human pathogen Staphylococcus aureus synthesizes triterpenoid carotenoid pigments (Marshall \& Wilmoth, 1981). Many Pseudomonas are known to have versatile metabolism (Rojo, 2010) and to synthesise pigments (Meyer \& Abdallah, 1978). Pseudomonas produces a yellow-green water soluble fluorescent siderophore pyoverdine, which is responsible for the capturing of iron (Meyer, 2000). Many streptomycetes also produce different pigments that, in caves with Paleolithic rock paintings, contribute notably to the 


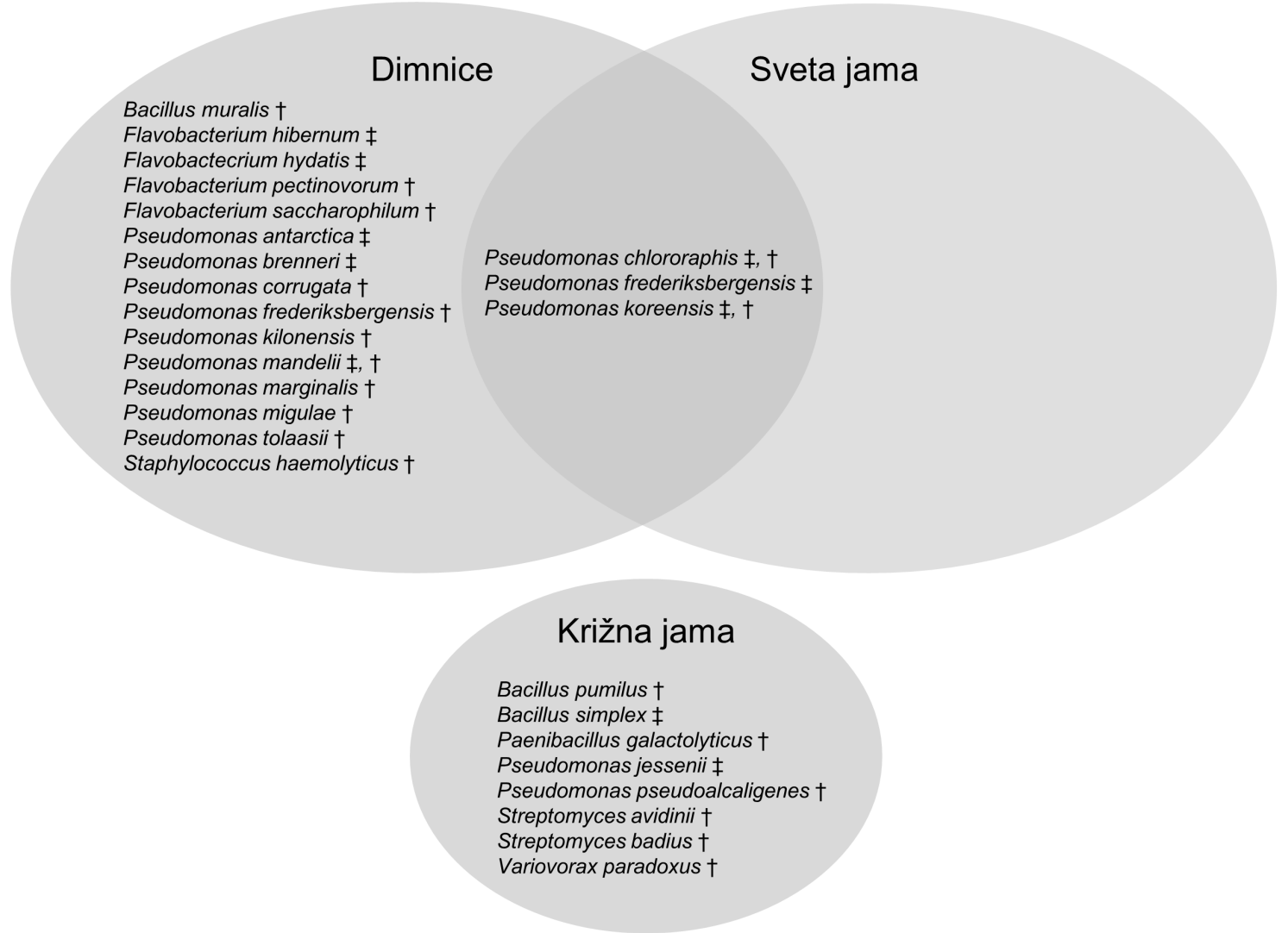

Fig. 2. Identified isolates from yellow subaerial biofilms from Dimnice, Sveta jama and Križna jama (†, MALDI score value 1.700-1.999 indicating secure identification of the genus; , MALDI score value 2.000-3.000 indicating secure identification of the species).

biodeterioration of rock art (Groth et al., 1999). The small number of streptomycetes revealed in this study can be linked to the selection of non-optimum growth media. At the moment it is not clear whether absorption and emission spectra of the biofilm (Fig. 3A, C, and E) belong to one microbial species or more, or whether they represent a combination of more pigments.

The yellow pigment is partially water soluble. This can be observed in caves when condensed water droplets on intact subaerial biofilms adopt a yellowish hue. Biofilms from all three analysed caves displayed a similar absorption maximum, in the violet part of the light spectrum. The absorption peak from Dimnice was at $407 \mathrm{~nm}$ when water was used as solvent, at $410 \mathrm{~nm}$ in acetone and at $393 \mathrm{~nm}$ in ethanol (Fig. 3A). Pigment from Križna jama showed an absorption peak at $419 \mathrm{~nm}$ in acetone, but in water and ethanol the peak was less well expressed than in the sample from Dimnice (Fig. 3C). Pigment from a Sveta jama sample had a maximum absorption in water at $400 \mathrm{~nm}$ (Fig. 3E). Pigments extracted in water were further excited by light at $405 \mathrm{~nm}$ (violet). The emission spectra were very similar for all samples having two emission peaks. In a Dimnice sample the major peak was at $460 \mathrm{~nm}$ (blue) with a minor one at $600 \mathrm{~nm}$ (orange) (Fig. 3A). In a sample from Križna jama, the major peak was at $460 \mathrm{~nm}$ and the minor peak at $602 \mathrm{~nm}$ (Fig. 3C). Similarly, the major peak for a Sveta jama sample was at $460 \mathrm{~nm}$ and the minor peak at $603 \mathrm{~nm}$ (Fig. 3E). Additional analyses are needed to help unravel the chemical structure of the pigment(s).

\section{Perception of yellow subaerial biofilm and its potential role}

The human colour perception of cave subaerial biofilms depends both upon the quality and quantity of the light that is used for illumination and on the presence or absence of a water film that acts as a magnifying glass over the microbial mats. Different light sources are used for exploration in caves and mines; in the past carbide lamps and candles were commonly used, but LED lamps have been used more recently. To a degree carbide lamps (Fig. 3B), wax candles (Fig. 3B) and halogen lamps (Fig. 3D) have similar spectra, with a large emission extending from the nominal red edge of the visible spectrum at $700 \mathrm{~nm}$ further towards the infrared area that is largely responsible for heat emission. Human colour perception of objects is different in the case of LED lamps. Analysis of emission spectra of the two commonly used cool white LED lamps showed two emission maxima, for the Petzl Duo at 469 and $556 \mathrm{~nm}$, and for the Scurion at 446 and $556 \mathrm{~nm}$ (Fig. 3D). Such LEDs emit light close to the absorption maximum of yellow biofilm, which is why such biofilms are more clearly traced in caves when they are illuminated by this type of lamp. Specifically, the relative low quantity of photons in the violet-blue part of the spectrum as against the orange-red part of the spectrum for carbide lamps and candles results in less fluorescence of yellow pigmented biofilms when these two lamps are used for lighting. How humans perceive colours depends also upon light intensity. When scotopic vision is dominant at luminance levels between of $10^{-2}$ and $10^{-6}$ Lux the luminous 

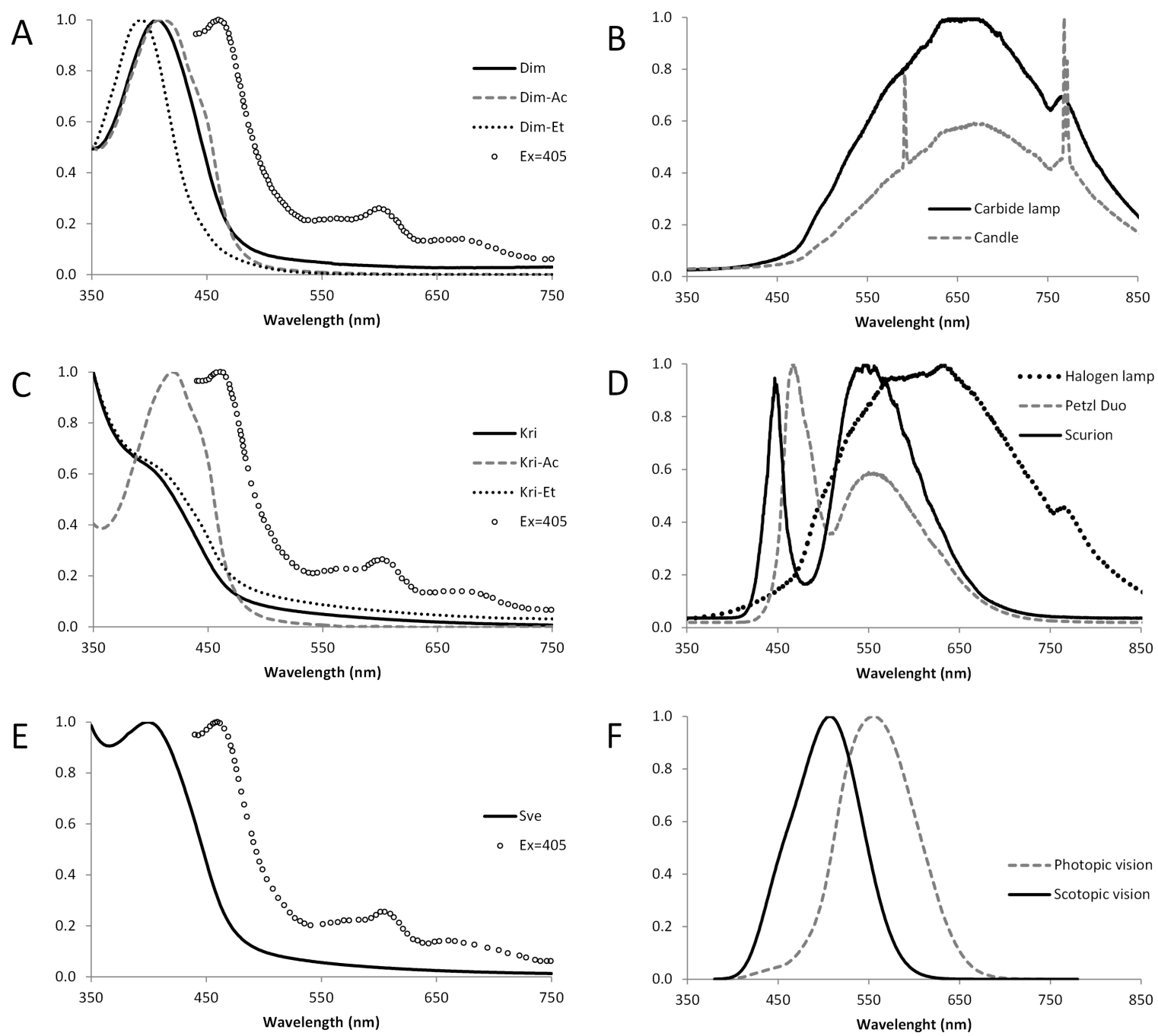

Fig. 3. Emission and absorption spectra: A) absorption spectra of subaerial biofilm from Dimnice after pigment extraction in deionized water (Dim), $90 \%$ acetone (Dim-Ac), 96\% ethanol (Dim-Et), and a fluorescence spectrum of the extract in deionized water when excited at $405 \mathrm{~nm}(\mathrm{Ex}=405)$; B) emission spectra of a carbide lamp and a candle; C) absorption spectra of subaerial biofilm from Križna jama after pigment extraction in deionized water (Kri), $90 \%$ acetone (Kri-Ac), $96 \%$ ethanol (Kri-Et), and a fluorescence spectrum of the extract in deionized water when excited at $405 \mathrm{~nm}(\mathrm{Ex}=405)$; D) emission spectra of a halogen lamp and a Petzl Duo LED caving lamp and a Scurion LED lamp; E) absorption spectra of subaerial biofilm from Sveta jama after pigment extraction in deionized water, and a fluorescence spectrum of the extract in deionized water when excited at $405 \mathrm{~nm}(E x=405) ; F)$ spectral luminous efficiency function for scotopic and photopic vision (Judd \& Wyszecki, 1975; Vos, 1978; Sharpe et al., 2005).

efficiency is different to that when photopic vision dominates (1-10 6 Lux). During periods of scotopic vision the human eye is most sensitive to light around $500 \mathrm{~nm}$, whereas the sensitivity peak shifts to a longer wavelength, around $550 \mathrm{~nm}$ during photopic vision (Fig. 3F) (Judd \& Wyszecki, 1975; Vos, 1978; Sharpe et al., 2005). Because of this physiological adaptation of human eyes, yellow subaerial biofilms are more vividly observed in comparison with other coloured mats in caves with generally low levels of illumination.

Many authors have studied coloured bacterial mats in lava tubes (Northup et al., 2011; Hathaway et al., 2014) and karst caves (Mulec, 2008; Pašić et al., 2010; Velikonja et al., 2014) but, nevertheless, little is yet known about their nature and role in subsurface ecosystems. In situations outside caves pigments from secondary metabolism can help to protect biofilms against lethal doses of UV irradiation, acting as "sunscreen" compounds (Gao \& Garcia-Porca, 2011); this is not the case inside caves. Roles in other ecological interactions should also be considered, e.g. protection against grazers by production of antibiotics, as with Streptomyces (Hobbs et al., 1990), or secretion of siderophores. Siderophores are important in virulence (pathogenicity) expression and development of biofilms by different microbes (Wynn-Williams et al., 2002; Saha et al., 2013).

Fluorescence of yellow subaerial biofilm is probably not directly linked solely to the most frequent natural fluorophores, such as aromatic amino acids, flavins, vitamin A, chlorophylls and NADH (Campbell \& Dwek, 1984). An absorption peak around $405 \mathrm{~nm}$ in the different solvents used indicates stability and potential biotechnological application, for example similar to the Green Fluorescent Protein, GFP. GFP is also very stable with tolerance to fixatives, detergents and chaotropes (Ward, 1998). Further studies are needed, not just to explain the role of pigmented subaerial biofilms in caves, but also to understand their interaction with cave surfaces as important players in changing cave micromorphology, e.g., biochemically induced etching of solid surfaces, and their potential use in biotechnology and medicine. Caves do offer an important biotechnological pool of 
microbes, for example in Carlsbad Cavern, USA, a microbe has been isolated that can degrade hazardous benzothiazole (Barton, 2006).

\section{CONCLUSIONS}

Yellow biofilms on surfaces in caves are an important source of live microorganisms. They are well-observed in caves due to the contrast with the surrounding surfaces, and recently more evident due to fluorescence characteristic of the pigment(s) related to the usage of cool white LEDs for illumination. It is not yet clear whether the two emission peaks from yellow biofilms are associated with the same pigment; nor is the role of pigment(s) in underground habitats fully understood. Subaerial biofilms that cover surfaces in caves are probably more widespread than current data suggest, but some of them are difficult to observe when the contrast with the underlying surface is low, for example white or transparent colonies on white rock surfaces. MALDI-TOF showed considerable promise as an identification and research tool for future use in cave microbiology.

\section{ACKNOWLEDGEMENTS}

The study was supported by the Slovenian Research Agency (J6-0152 and L1-5453). The authors acknowledge Franci Malečkar, Peter Kozel and Lojz Troha for field assistance, Dragan Abram and Jurij Hajna for help on data processing, Nadja Zupan Hajna and Mitja Prelovšek for comments on an earlier version of the manuscript, and David Lowe for language editing assistance.

\section{REFERENCES}

Ban F., Pan G., Zhu J., Cai B. \& Tan M., 2008 - Temporal and spatial variations in the discharge and dissolved organic carbon of drip waters in Beijing Shihua Cave, China. Hydrological Processes, 22: 3749-3758. http://dx.doi.org/10.1002/hyp.6979

Barton H.A., 2006 - Introduction to cave microbiology: a review for the non-specialists. Journal of Cave and Karst Studies, 68: 43-64.

Bosak P., Pruner P., Zupan Hajna N., Hercman H., Mihevc A. \& Wagner J., 2010 - Križna jama (SW Slovenia): Numerical- and correlated-ages from cave bear-bearing sediments. Acta Carsologica, 39: 529-549.

Brennan E. \& White W.B., 2013 - Luminescence of speleothems: a comparison of sources and environments. Journal of Cave and Karst Studies, 75: 210-217. http://dx.doi.org/10.4311/2012ES0280

Brooks B.W., Murray R.G.E., Johnson J.L., Stackebrandt E., Woese C.R. \& Fox G.E., 1980 - Red-pigmented micrococci: a basis for taxonomy. International Journal of Systematic and Evolutionary Microbiology, 30: 627-646. http://dx.doi.org/10.1099/00207713-30-4-627

Buser S., Grad K. \& Pleničar M., 1967 - Basic geological map of SFRY 1:100.000, sheet Postojna. Belgrade: Federal Geological Survey (in Slovene).

Campbell I.D. \& Dwek R.A., 1984 - Biological spectroscopy. Benjamin/Cummings Pub. Co., Menlo Park, California, $404 \mathrm{p}$.
Cuezva S., Fernandez-Cortes A., Porca E., Pasic L., Jurado V., Hernandez-Marine M., Serrano-Ortiz P., Hermosin B., Cañaveras J.C., Sanchez-Moral S. \& Saiz-Jimenez C., 2012 - The biogeochemical role of actinobacteria in Altamira Cave, Spain. FEMS Microbiology Ecology, 81: 281-290.

http://dx.doi.org/10.1111/j.1574-6941.2012.01391.x

Dattagupta S., 2014 - Introduction to the special issue "Biogeochemistry and microbial ecology of cave systems". Geomicrobiology Journal, 31: 173-174. http://dx.doi.org/10.1080/01490451.2014.864875

Dufosse L., 2006 - Microbial production of food grade pigments. Food Technology and Biotechnology, 44: 313-321.

Gao Q. \& Garcia-Porca F., 2011 - Microbial ultraviolet sunscreens. Nature Reviews Microbiology, 9: 791-802.

Gorbushina A., 2007 - Life on the rocks. Environmental Microbiology, 9: 1613-1631.

http://dx.doi.org/10.1111/j.1462-2920.2007.01301.x

Gospodarič R., 1974 - Fluvial sediments in Križna jama. Acta Carsologica, 6: 327-366.

Groth I., Vetterman R., Schuetze B., Schumann P. \& Saiz-Jimenez C., 1999 - Actinomycetes in karstic caves of northern Spain (Altamira and Tito Bustillo). Journal of Microbiological Methods, 36: 115-122. http://dx.doi.org/10.1016/S0167-7012(99)00016-0

Hathaway J., Garcia M., Balasch M., Spilde M., Stone F., Dapkevicius M.L.N.E, Amorim I.R., Gabriel R., Borges P.A.V. \& Northup D.E., 2014 - Comparison of bacterial diversity in Azorean and Hawai'ian lava cave microbial mats. Geomicrobiology Journal, 31: 205-220. http://dx.doi.org/10.1080/01490451.2013.777491

Hobbs G., Frazer C.M., Gardner D.C., Flett F. \& Oliver S.G., 1990 - Pigmented antibiotic production by Streptomyces coelicolor A3(2): kinetics and the influence of nutrients. Microbiology, 136: 2291-2296.

http://dx.doi.org/10.1099/00221287-136-11-2291

Ichiyama S., Shimokata K. \& Tsukamura M., 1989 Carotenoid pigments of genus Rhodococcus. Microbiology and Immunology, 33: 503-508.

http://dx.doi.org/10.1111/j.1348-0421.1989.tb01999.x

Judd D.B., 1975 - Wyszecki G. Color in business, science and industry ( $3^{\text {rd }}$ ed.). John Wiley \& Sons, New York, 553 p.

Keiner R., Frosch T., Hanf S., Rusznyak A., Akob D., Kusel K. \& Popp J., 2013 - Raman spectroscopy-an innovative and versatile tool to follow the respirational activity and carbonate biomineralization of important cave bacteria. Analytical Chemistry, 85: 8708-8714. http://dx.doi.org/10.1021/ac401699d

Krištůfek V., Elhottová D., Chroňáková A., Dostálková I., Picek T. \& Kalčik J., 2005 - Growth strategy of heterotrophic bacterial population along successional sequence on spoil of brown coal colliery substrate. Folia Microbiologica, 50: 427-435. http://dx.doi.org/10.1007/BF02931425

Laiz L., Gonzalez-Delvalle M., Hermosin B., OrtizMartinez A. \& Saiz-Jimenez C., 2003 - Isolation of cave bacteria and substrate utilization at different temperatures. Geomicrobiology Journal, 20: 479-489. http://dx.doi.org/10.1080/713851125

Malečkar F. \& Gospodarič R., 1982 - Geology of the cave Dimnice (Matarsko podolje-Slovenia). Atti $5^{\circ}$ convegno regionale di speleologia del Friuli-Venezia Giulia, Trieste: 243-249 (in Italian).

Marshall J. \& Wilmoth G., 1981 - Pigments of Staphylococcus aureus, a series of triterpenoid carotenoids. Journal of Bacteriology, 147: 900-913. 
McGarry S. \& Baker A., 2000 - Organic acid fluorescence: applications to speleothem palaeoenvironmental reconstruction. Quaternary Science Reviews, 19: 1087-1101.

http://dx.doi.org/10.1016/S0277-3791(99)00087-6

Meyer J., 2000 - Pyoverdines: pigments, siderophores and potential taxonomic markers of fluorescent Pseudomonas species. Archives of Microbiology, 174: 135-142. http://dx.doi.org/10.1007/s002030000188

Meyer J.M. \& Abdallah M.A., 1978 - The fluorescent pigment of Pseudomonas fluorescens: biosynthesis, purification and physicochemical properties. Journal of General Microbiology, 107: 319-328.

http://dx.doi.org/10.1099/00221287-107-2-319

Mulec J., 2008 - Microorganisms in hypogeon: examples from Slovenian karst caves. Acta Carsologica, 37: 153-160.

Mulec J., 2012 - Lampenflora. In: White W. \& Culver D.C. (Eds.), Encyclopedia of caves. Elsevier, Amsterdam, p. 451-456.

http://dx.doi.org/10.1016/B978-0-12-383832-2.00064-5

Mulec J., Krištůfek V. \& Chroňáková A., 2012a Monitoring of microbial indicator groups in caves through the use of RIDA ${ }^{\circledR}$ COUNT kits. Acta Carsologica, 41: 287-296. http://dx.doi.org/10.3986/ac.v41i2-3.565

Mulec J., Krištůfek V. \& Chroňáková A., 2012b Comparative microbial sampling from eutrophic caves in Slovenia and Slovakia using RIDA ${ }^{\circledR}$ COUNT test kits. International Journal of Speleology, 41: 1-8. http://dx.doi.org/10.5038/1827-806X.41.1.1

Mulec J., Zalar P., Zupan Hajna N. \& Rupnik M., 2002 - Screening for culturable microorganisms from cave environments (Slovenia). Acta Carsologica, 31: 177-187.

Northup D., Melim L., Spilde M., Hathaway J., Garcia M., Moya M., Stone F.D., Boston P.J., Dapkevicius M.L.N.E. \& Riquelme C., 2011 - Lava cave microbial communities within mats and secondary mineral deposits: implications for life detection on other planets. Astrobiology, 11: 601-618.

http://dx.doi.org/10.1089/ast.2010.0562

Pašić L., Kovče B., Sket B. \& Herzog-Velikonja B., 2010 - Diversity of microbial communities colonizing the walls of a karstic cave in Slovenia. FEMS Microbiology, Ecology, 21: 50-60.

Pleničar M., Polšak A. \& Šikić D., 1969 - Basic geological map of SFRY 1:100.000, sheet Trst. Belgrade: Federal Geological Survey (in Slovene).

Porca E., Jurado V., Zgur-Bertok D., Saiz-Jimenez C. \& Pasic L., 2012 - Comparative analysis of yellow microbial communities growing on the walls of geographically distinct caves indicates a common core of microorganisms involved in their formation. FEMS Microbiology Ecology, 81: 255-266.

http://dx.doi.org/10.1111/j.1574-6941.2012.01383.x

Portillo M., Gonzalez J. \& Saiz-Jimenez C., 2008 Metabolically active microbial communities of yellow and grey colonizations on the walls of Altamira Cave, Spain. Journal of Applied Microbiology, 104: 681-691. http://dx.doi.org/10.1111/j.1365-2672.2007.03594.x

Portillo M., Saiz-Jimenez C. \& Gonzalez J., 2009 Molecular characterization of total and metabolically active bacterial communities of "white colonizations" in the Altamira Cave, Spain. Research in Microbiology, 160: 41-47. http://dx.doi.org/10.1016/j.resmic.2008.10.002

Prelovšek M., 2012 - The dynamics of the present-day speleogenetic processes in the stream caves of Slovenia. ZRC Publishing, Ljubljana, $152 \mathrm{p}$.
Rojo F., 2010 - Carbon catabolite repression in Pseudomonas: optimizing metabolic versatility and interactions with the environment. FEMS Microbiology Reviews, 34: 658-684.

Saha R., Saha N., Donofrio R.S. \& Bestervelt L.L., 2013 Microbial siderophores: a mini review. Journal of Basic Microbiology, 53: 303-317. http://dx.doi.org/10.1002/jobm.201100552

Saiz-Jimenez C., Cuezva S., Jurado V., FernandezCortes A., Porca E., Benavente D., Cañaveras J.C. \& Sanchez-Moral S., 2011 - Paleolithic art in peril: policy and science collide at Altamira Cave. Science, 333: 42-43. http://dx.doi.org/10.1126/science.1206788

Seng P., Drancourt M., Gouriet F., La Scola B., Fournier P.E., Rolain J.M. \& Raoult D., 2009 - Ongoing revolution in bacteriology: routine identification of bacteria by matrix-assisted laser desorption ionization time-of-flight mass spectrometry. Clinical Infectious Diseases, 49: 543-551. http://dx.doi.org/10.1086/600885

Sharpe L., Stockman A., Jagla W. \& Jagle H., 2005 A luminous efficiency function, $V^{*}(\lambda)$, for daylight adaptation. Journal of Vision, 5: 948-968.

http://dx.doi.org/10.1167/5.11.3

Shirling E.B. \& Gottlieb D., 1966 - Methods for characterization of Streptomyces species. International Journal of Systematic and Evolutionary Microbiology, 16: 313-340.

http://dx.doi.org/10.1099/00207713-16-3-313

Slabe T., 1988 - Condense corrosion on rocky rim of Komar Channel in Dimnice. Acta Carsologica, 17: 79-92.

Slabe T., 1989 - Rocky features in Križna jama and their meaning for speleogenesis. Acta Carsologica, 18: 199-220.

Slabe T., 1995 - Cave rocky relief and its speleogenetical significance. Znanstvenoraziskovalni center SAZU, Ljubljana, $128 \mathrm{p}$.

Šikić D., Pleničar M. \& Šparica M., 1972 - Basic geological map of SFRY 1:100.000, sheet Ilirska Bistrica. Belgrade: Federal Geological Survey (in Slovene).

Tobie W.C., 1945 - A proposed biochemical basis for the genus Pseudomonas. Journal of Bacteriology, 49: 459.

Velikonja B., Tkavc R. \& Pasic L., 2014 - Diversity of cultivable bacteria involved in the formation of macroscopic microbial colonies (cave silver) on the walls of a cave in Slovenia. International Journal of Speleology, 43: 45-56.

http://dx.doi.org/10.5038/1827-806X.43.1.5

Vos J.J., 1978 - Colorimetric and photometric properties of a $2^{\circ}$ fundamental observer. Color Research and Application, 3: 125-128. http://dx.doi.org/10.1002/col.5080030309

Ward W.W., 1998 - Biochemical and physical properties of green fluorescent protein. In: Chalfie M. \& Kain S. (Eds.), Green fluorescent protein, properties, applications, and protocols. New-York: Wiley-Liss: 45-75.

Wynn-Williams D.D., Edwards H.G.M., Newton E.M. \& Holder J.M., 2002 - Pigmentation as a survival strategy for ancient and modern photosynthetic microbes under high ultraviolet stress on planetary surfaces. International Journal of Astrobiology, 1: 39-49. http://dx.doi.org/10.1017/S1473550402001039

Zhou L., Wang J., Wang J., Poplawsky A., Lin S., Zhu B, Chang C., Zhou T., Zhang L.H. \& He Y.W., 2013 The diffusible factor synthase XanB2 is a bifunctional chorismatase that links the shikimate pathway to ubiquinone and xanthomonadins biosynthetic pathways. Molecular Microbiology, 87: 80-93. http://dx.doi.org/10.1111/mmi.12084 